\title{
Editorial: Resource Recovery From Waste
}

\author{
Alfonso J. Lag-Brotons ${ }^{1 *}$, Anne P. M. Velenturf ${ }^{2}$, Richard Crane ${ }^{3,4}$, lan M. Head ${ }^{5}$, \\ Phil Purnell ${ }^{2}$ and Kirk T. Semple ${ }^{1}$ \\ ${ }^{1}$ Lancaster Environment Centre, Lancaster University, Lancaster, United Kingdom, ${ }^{2}$ School of Civil Engineering, University of \\ Leeds, Leeds, United Kingdom, ${ }^{3}$ Camborne School of Mines, College of Engineering, Mathematics and Physical Sciences, \\ University of Exeter, Penryn, United Kingdom, ${ }^{4}$ Environment and Sustainability Institute, University of Exeter, Penryn, \\ United Kingdom, ${ }^{5}$ School of Natural and Environmental Sciences, Newcastle University, Newcastle upon Tyne, \\ United Kingdom
}

Keywords: circular economy, resource recovery from waste, biogeochemical technologies, sustainable transition, whole system design, bio-economy, participatory action research, complex value

\section{Editorial on the Research Topic}

\section{Resource Recovery From Waste}

\section{INTRODUCTION}

The inefficient global use of resources has stressed, stretched, and surpassed safe operating conditions for humanity within the biophysical environment (Rockström et al., 2009). Exponential growth in resource exploitation and consumption has resulted in shortages of materials and severe and sustained environmental impacts that are now adversely affecting human well-being [UNEP (United Nations Environment Programme) and ISWA (International Solid Waste Association), 2015; UNEP, 2016; Raworth, 2017]. Our current linear economy, in which we extract, process, use and dispose of resources, has resulted in the dual crisis of waste overload and resource scarcity (Velenturf and Purnell, 2017). With the negative impacts of unsustainable resource exploitation on environment, society, and economy mounting up, it is of critical importance to make a transition toward a more sustainable economic system in which we make better use of resources (Macaskie et al., 2019).

Circular economy has been proposed as a more sustainable alternative to the linear economy [Stahel, 2016; EMF (The Ellen MacArthur Foundation), 2017; Velenturf and Jopson, 2019]. Circular economy is a broad concept with diverse definitions, yet all sharing a determination to achieve greater resource efficiency combined with "green growth" and associated social benefits (Ghisellini et al., 2016; D’Amato et al., 2017; Kirchherr et al., 2017; Murray et al., 2017). Circular economy is still a fluid concept requiring fundamental research, in particular regarding the biophysical limitations of realizing closed loops of material flows (Velenturf et al., 2019a) and the ability of circular economy to contribute to sustainable development (Schroeder et al., 2018). While research into circular economy is on-going, implementation of aspects of circular practice in and by companies, cities, regions, and countries has gained momentum worldwide (Purnell et al., 2019b). In the UK, for example, circular economy practices are being implemented to maximize resource productivity, enable economic growth, and restore the natural environment (Report of the Government Chief Scientific Adviser, 2016; HM Government, 2017, 2018).

Resource Recovery from Waste (RRfW) represents a transition stage toward a sustainable circular economy. Circular economy encompasses a wide range of strategies, including design for durability, reuse and reparability, recycling and recovering materials, energy recovery, and controlled storage in landfills (Velenturf et al., 2019b). The implementation of RRfW 
within a circular economy requires action across society, including industry, politicians, NGOs, communities, and academia. Academia plays a key role in building the evidence base for circular economy implementation and has a unique ability in maintaining a whole system perspective, with the capacity to identify key intervention points and co-produce actions with actors to advance circular economy, and to appraise and evaluate the effects of such actions on progress toward a more sustainable circular economy (Velenturf et al., 2018).

New technologies are continually required in order to optimize the recovery of resources from waste flows (Macaskie et al., 2019). Technologies incorporating biological processes are of particular interest, due to their potential to perform complex functions by harnessing natural processes to: (a) process integrated waste resource flows; (b) selectively recover target materials such as metals; and (c) achieve high recovery rates with minimal energy input. The articles featured in this Frontiers Research Topic build on this potential.

\section{HIGHLIGHTS FROM PUBLICATIONS FEATURED IN THIS RESEARCH TOPIC}

Mikheenko et al. proposed an integrated process with sidestream upgrading of a by-product of biogas generation (5-hydroxymethyl furfural to 2, 5-dymethil furan) to reduce the energy need on biomass hydrothermal processing prior to anaerobic digestion. Bacterially supported palladium $(\mathrm{Pd}) /$ ruthenium $(\mathrm{Ru})$ nanoparticles derived from two different microbial consortiums (sulfate-reducing bacterium \& acidophilic sulfidogens) were used as catalysts. Amongst others, they discussed a novel aspect such as the role of $\mathrm{Pb}$ and $\mathrm{Ru}$ sulfides in hydrogenation.

Joshi et al. discovered that the bacterium Geobacter sulfurreducens exhibits the ability to produce magnetic Fe(II)bearing nanoparticles from $\mathrm{Fe}$ (III) minerals, thus with great potential for use in bioremediation applications. Beyond laboratory testing, life cycle assessment, and costing were carried out, with positive results on the production of this magnetic nanomaterial.

The research carried out by Stephen et al. is applicable to renewable energy production, focusing on the production of alternative catalysts for $\mathrm{H}_{2}$ fuelled engines. They provided a starting point for the biogenic generation of platinum $(\mathrm{Pt}) /$ palladium $(\mathrm{Pb})$ nanoparticles synthesized by E.coli for direct use in polymer electrolyte fuel cells, including its comparison with conventional chemically synthesized ones.

Maleke et al. focused on the development of a process for the biological recovery of Europium (Eu). They assessed the performance of Thermus scotoductus SA-01 regarding Eu bioaccumulation and biomineralization under thermophilic conditions, concluding that it was a suitable candidate for $\mathrm{Eu}$ biorecovery in rare earth metal-containing carbonates.

Organic waste streams could yield different valuable compounds depending on the process operating conditions and biochemical pathways. In this respect, Pagliano et al. used dairy industry by-products as substrates for anaerobic digestion, aiming to gain a better understanding of the microbiota structure and functionality in the generation of $\mathrm{H}_{2}$ by culture-independent methods.

Improving the understanding of the biological process by which the organic fraction municipal solid waste (OFMSW) used as substrate for bioethanol production was the focus of Carrillo-Barragan et al.. They tested whether the OFMSW could be degraded by microorganisms sourced from different inocula where lignocellulose degradation putatively occurs. They demonstrated that the interaction of inocula and initial $\mathrm{pH}$ directed the ethanologenic activity and that the combination of two inocula resulted in wider functionality resilience.

Lastly, Akram et al. assessed how increased spatial resolution of input data affected the optimization of a model considering weight, distance, and spatial patterns on the cost-effectiveness of transport of organic waste (animal/human excreta) used as fertilizer in Sweden and Pakistan.

\section{FUTURE RESEARCH}

This Research Topic collection advances our understanding on the emerging and important role that bio-related technologies can play in RRfW, but also on challenges and future research directions. As shown by Mikheenko et al., Joshi et al., and Stephen et al., better understanding on nanoparticle composition, role (e.g., catalyst) within the bioprocess and associated cost of production (including upscaling) is required. Given the importance of microorganisms on the bioprocesses, advances on (meta)genetics is a way forward, specifically aiming to identify genes exerting the desired/undesired effects (e.g., metal influx and efflux) and microbial species/consortiums carrying them out (Maleke et al.; Pagliano et al.). Beyond this, there is further research interest into conditions and how different waste streams affect bioprocesses (Carrillo-Barragan et al.). Akram et al. acknowledged the importance of better data on resources, in terms of quantity, quality, geolocation, and time of resources becoming available, at different scales for effective RRfW.

The research gaps identified in this Research Topic collection complement on-going challenges and research opportunities that were identified by academic and public, private, and civil sector partners of the Resource Recovery from Waste programme ${ }^{1}$ including for example (Jopson and Velenturf, 2019; Purnell et al., 2019a):

- Develop systems-based approaches that take into account consistent metrics, indicators and criteria that better measure environmental, social, technical, and economic costs and benefits to inform decision-making in e.g., industry and governance throughout lifecycles of materials;

- Design better systems to collect and use data on the quantity, quality, and location in time and space of resources at local, regional and national scales;

\footnotetext{
${ }^{1}$ https://rrfw.org.uk/
} 
- Economic and business models which can generate social and environmental net-gains while improving or maintaining economic prosperity;

- Greater alignment of all stages in production-consumption systems, aligning product design with responsible consumption patterns and "downstream" waste processing infrastructure, such as the bio-related technologies discussed herein, to ensure that the value of all materials and products that are placed onto markets can be maintained for as long as possible.

Further research combined with practical advances is urgently required for the rapid implementation of a sustainable circular economy that can improve environmental quality, social well-being and economic prosperity.

\section{REFERENCES}

D’Amato, D., Droste, N., Allen, B., Kettunen, M., Lähtinen, K.,Korhonen, J., et al. (2017). Green, circular, bio economy: a comparative analysis of sustainability avenues. J. Clean. Prod. 168, 716-734. doi: 10.1016/j.jclepro.2017. 09.053

EMF (The Ellen MacArthur Foundation) (2017). Achieving Growth Within (accessed January 31, 2020).

Ghisellini, P., Cialani, C., and Ulgiati, S. (2016). A review on circular economy: the expected transition to a balanced interplay of environmental and economic systems. J. Clean. Prod. 114, 11-32. doi: 10.1016/j.jclepro.2015.09.007

HM Government (2017). Industrial Strategy - Building Britain Fit for the Future. London.

HM Government (2018). Our Waste, Our Resources: A Strategy for England. London.

Jopson, J., and Velenturf, A. P. M. (2019). "Research and innovation challenges for resource recovery and circular economy," in Workshop Proceedings (Swindon).

Kirchherr, J., Reike, D., and Hekkert, M. (2017). Conceptualising the circular economy - an analysis of 114 definitions. Resour. Conserv. Recycl. 127, 221-232. doi: 10.1016/j.resconrec.2017.09.005

Macaskie, L. E., Sapsford, D. J., and Mayes, W. M. (2019). Resource Recovery from Wastes: Towards a Circular Economy. London: The Royal Society of Chemistry; Green Chemistry Series, 444.

Murray, A., Skene, K., and Haynes, K. (2017). The circular economy: an interdisciplinary exploration of the concept and application in a global context. J. Bus. Ethics 140, 369-380. doi: 10.1007/s10551-015-2693-2

Purnell, P., Jopson, J., Velenturf, A., Mayes, W., Sapsford, D., Macaskie, L. et al. (2019a). Resource Recovery From Waste (End of Programme Brochure). Leeds, 49.

Purnell, P., Velenturf, A. P. M., and Marshall, R. (2019b). "Chapter 16: New Governance for Circular Economy: Policy, Regulation and Market Contexts for Resource Recovery from Waste," in Resource Recovery from Wastes: Towards a Circular Economy, eds L. Macaskie, D. Sapsford, and W. Mayes (Royal Society of Chemistry), 395-422.

Raworth, K. (2017). Doughnut Economics: Seven Ways to Think Like a 21st-Century Economist. London: Random House Business Books.

Report of the Government Chief Scientific Adviser (2016). From Waste to Resource Productivity. London: The Government Office for Science.

Rockström, J., Steffen, W., Noone, K., Persson, A., Chapin, F. S. III., Lambin, E. F., et al. (2009). A safe operating space for humanity. Nature 461, 472-475. doi: $10.1038 / 461472 \mathrm{a}$

\section{AUTHOR CONTRIBUTIONS}

All authors contributed to the production of this editorial. AL-B and $\mathrm{AV}$ produced the initial draft and coordinated the editorial writing process. AL-B, AV, and RC contributed to produce a consolidated version. $\mathrm{PP}, \mathrm{KS}$, and $\mathrm{IH}$ refined the consolidated version. All authors revised the final version.

\section{ACKNOWLEDGMENTS}

Authors would like to acknowledge NERC, ESRC, and DEFRA for the funds and resources for the Resource Recovery from Waste (RRfW) programme provided via grant code NE/L014149/1, which have made this Frontiers Research Topic possible.

Schroeder, P., Anggraeni, K., and Weber, U. (2018). The relevance of circular economy practices to the sustainable development goals. J. Indus. Ecol. 23, 77-95. doi: 10.1111/jiec.12732

Stahel, W. (2016). The circular economy. Nature. 531, 435-438 doi: $10.1038 / 531435 \mathrm{a}$

UNEP (2016). "Global material flows and resource productivity," in An Assessment Study of the UNEP International Resource Panel, eds H. Schandl, M. FischerKowalski, J. West, S. Giljum, M. Dittrich, N. Eisenmenger, A. Geschke, M. Lieber, H. P. Wieland, A. Schaffartzik, F. Krausmann, S. Gierlinger, K. Hosking, M. Lenzen, H. Tanikawa, A. Miatto, and T. Fishman (Paris: United Nations Environment Programme).

UNEP (United Nations Environment Programme) and ISWA (International Solid Waste Association) (2015). Global Waste Management Outlook.

Velenturf, A. P. M., Archer, S. A., Gomes, H. I., Christgen, B., Lag-Brotons, A. J., and Purnell, P. (2019a). Circular economy and the matter of integrated resources. Sci Tot. Environ. 689, 963-969. doi: 10.1016/j.scitotenv.2019.06.449

Velenturf, A. P. M., and Jopson, S. J. (2019). Making the business case for resource recovery. Sci. Tot. Environ. 648, 1031-1041. doi: 10.1016/j.scitotenv.2018.08.224

Velenturf, A. P. M., and Purnell, P. (2017). Resource recovery from waste: restoring the balance between resource scarcity and waste overload. Sustainability 9:1603. doi: 10.3390/su9091603

Velenturf, A. P. M., Purnell, P., Macaskie, L., Sapsford, D., and Mayes, W. (2019b). "Chapter 1. A new perspective on a global circular economy," in Resource Recovery from Wastes: Towards a Circular Economy, eds L. Macaskie, D. Sapsford, and W. Mayes (Royal Society of Chemistry), 1-22.

Velenturf, A. P. M., Purnell, P., Tregent, M., Ferguson, J., and Holmes, A. (2018). Co-producing a vision and approach for the transition towards a circular economy: perspectives from government partners. Sustainability, 10:1401. doi: $10.3390 /$ su10051401

Conflict of Interest: The authors declare that the research was conducted in the absence of any commercial or financial relationships that could be construed as a potential conflict of interest.

Copyright (C) 2020 Lag-Brotons, Velenturf, Crane, Head, Purnell and Semple. This is an open-access article distributed under the terms of the Creative Commons Attribution License (CC BY). The use, distribution or reproduction in other forums is permitted, provided the original author(s) and the copyright owner(s) are credited and that the original publication in this journal is cited, in accordance with accepted academic practice. No use, distribution or reproduction is permitted which does not comply with these terms. 